Review Article

\title{
Research Progress on the Antiosteoarthritic Mechanism of Action of Natural Products
}

\author{
Mingzhu Gao $\mathbb{D}^{1,2,3}$ Chun Chen, ${ }^{1,2,3}$ Qiaoyan Zhang, ${ }^{4}$ Jun Bian, ${ }^{3}$ Luping Qin $\mathbb{D}^{4}{ }^{4}$ \\ and Leilei Bao iD $1,2,4$ \\ ${ }^{1}$ Department of Pharmacy, Eastern Hepatobiliary Surgery Hospital, Second Military Medical University, Shanghai 200438, China \\ ${ }^{2}$ Jiangxi University of Traditional Chinese Medicine, Nanchang 330000, China \\ ${ }^{3}$ College of Pharmacy, Zhejiang Chinese Medical University, Hangzhou 310000, China \\ ${ }^{4}$ Department of Pharmacy, Changhai Hospital, Second Military Medical University, Shanghai 200433, China
}

Correspondence should be addressed to Luping Qin; lpqin@zcmu.edu.cn and Leilei Bao; annabao212@126.com

Received 21 April 2021; Revised 2 September 2021; Accepted 14 September 2021; Published 30 September 2021

Academic Editor: Antonella Fioravanti

Copyright ( $) 2021$ Mingzhu Gao et al. This is an open access article distributed under the Creative Commons Attribution License, which permits unrestricted use, distribution, and reproduction in any medium, provided the original work is properly cited.

Background. Osteoarthritis (OA) is a clinical joint degenerative disease, the pathogenic factors of which include age, obesity, and mechanical injury. Its main pathological features include cartilage loss, narrowing of joint space, and osteophyte formation. At present, there are a variety of treatment methods for OA. Natural products, which are gradually being applied in the treatment of OA, are advantageous as they present with low toxicity and low costs and act on multiple targets. Methods. The terms "natural products," "osteoarthritis," and "chondrocytes" were searched in PubMed to screen the related literature in the recent 10 years. Results. We comprehensively introduced 62 published papers on 48 natural products involving 6, 3, 5, 12, 4, and 5 kinds of terpenoids, polysaccharides, polyphenols, flavonoids, alkaloids, and saponins, respectively (and others). Conclusion. The mechanisms of their anti-OA action mainly involve reducing the production of inflammatory factors, reducing oxidative stress, regulating the metabolism of chondrocytes, promoting the proliferation of chondrocytes, or inhibiting chondrocyte apoptosis. This article summarizes the anti-OA activity of natural products in the last 10 years and provides candidate monomers for further study for use in OA treatment.

\section{Introduction}

Osteoarthritis (OA) is a common orthopedic disease worldwide. It is characterized by articular cartilage loss, subchondral bone changes, osteophyte formation, and synovitis [1]. Genetic factors, mechanical damage, age, and obesity are risk factors for OA. Articular cartilage injury includes degradation of the extracellular matrix (ECM) and apoptosis of chondrocytes. Abnormally elevated inflammatory factors in the synovial fluid interact with receptors on the membrane of chondrocytes and interfere with the normal functioning of some signaling pathways in these cells. They equally mediate the transcription of specific genes, causing apoptosis or degradation of the ECM of chondrocytes, leading to the further progression of OA [2].
The main goals of the treatment of $\mathrm{OA}$ under the modern medical system are to improve or maintain joint function, prevent the progression of $\mathrm{OA}$, and reduce pain. This treatment includes drug and nondrug therapy. Drug therapy is mostly symptomatic and involves the use of oral nonsteroidal anti-inflammatory drugs (NSAIDs), such as acetaminophen, celecoxib, and diclofenac, topical capsaicin cream, intra-articular glucocorticoid injections, and opioid drugs such as codeine, for moderate to moderately severe pain. Intra-articular injection of steroids or hyaluronic acid and its derivatives is another treatment option. There also exist other treatment options such as joint replacement surgery and physical exercise.

Recently, there have been increasing reports of natural animal and plant components that possess anti-inflammatory, antiapoptotic, proliferation-promoting, oxidation- 
inhibiting, and other pharmacological effects in OA, especially on articular chondrocytes [3]. Also, natural products should be assessed by modern western medicine methods. In this paper, the main monomers occurring in natural products with reported therapeutic effects in OA in the recent years are summarized. This can provide candidate monomers for the drug therapy of OA.

\section{Materials and Methods}

The terms "natural products," "osteoarthritis," and "chondrocytes" were searched in PubMed to screen the related literature in the recent 10 years. Then, it is classified according to structure and pharmacological action.

\section{Antiosteoarthritic Action of Natural Products}

Some studies have found that natural products possess better anti-OA effects than traditional drugs, such as glucosamine and chondroitin. Researchers are increasingly interested in the use of natural products in the treatment of OA [4]. At present, terpenoids, polyphenols, flavonoids, quinones, phenolic acids, polysaccharides, alkaloids, saponins, and other natural products have been found to have antiosteoarthritic effects.

3.1. Terpenoids. Terpenoids are basic substances involved in plant growth and metabolism [5]. Terpenoids elicit antiinflammatory and anticancer effects by acting on multiple targets. They can inhibit the activation of NOD-like receptor family pyrin domain containing 3 (NLRP3) inflammatory body, so as to regulate the pathogenicity of inflammatory diseases, such as colitis and gouty arthritis. The combined inhibition of TLR4-The noncanonical nuclear factor-kappa $\mathrm{B}(\mathrm{NF}-\kappa \mathrm{B})$ and NLRP3 inflammatory activation process may make terpenoids a very promising candidate for the development of safe and effective new therapies for NLRP3 inflammatory diseases. D-limonene belongs to monoterpenoids. In the orthotopic mouse model of human gastric cancer, d-limonene may inhibit tumor growth and metastasis through its antiangiogenesis, antiapoptosis, and antioxidant effects. Further evidence from a phase I clinical trial showed that one breast cancer patient was partially relieved, and three CRC patients were stable for more than six months. Poria acid, a wool triterpene derived from Poria cocos, shows cytotoxicity to human lung cancer A549 cells, human prostate cancer DU145 cells, and colon cancer HT29 cells and induces apoptosis of DU145 and LNCaP prostate cancer cells $[6,7]$. Many studies have found that terpenoids possess considerable antiosteoarthritic effects such as aucubin, abietic acid, andrographolide, gentiopicroside, monotropein, and celastrol. The specific mechanism of anti$\mathrm{OA}$ is described in Section 3. The chemical structures shown in Figure 1 are terpenoids with antiosteoarthritic properties.

3.2. Polysaccharides. Polysaccharides are important active compounds in traditional Chinese medicine (TCM). Polysaccharides obtained from TCMs exhibit a variety of biological activities such as reducing the concentration of inflammatory factors and increasing resistance to viruses and tumors. The polysaccharide extracted from Gelidium cartilagineum has anti-influenza B and mumps virus activity. Astragalus polysaccharide has anti-infectious bursal disease virus, porcine circovirus type 2 virus, duck hepatitis A virus, human hepatitis $\mathrm{B}$ virus, porcine reproductive and respiratory syndrome virus, and classical swine fever virus. Lycium barbarum polysaccharides and Angelica sinensis polysaccharides kill tumor cells by inducing apoptosis. Radix Hedysari polysaccharides and Achyranthes bidentata polysaccharides can inhibit cell cycle and play an antitumor role. Traditional Chinese medicine polysaccharides do not act on tumor cells, but play a role by activating the immune system, such as Sophora flavescens polysaccharide and Sanguisorba officinalis polysaccharide [8]. Polysaccharides are generally safe and nonirritating and have been widely used in the treatment of OA [9]. In recent years, in-depth research has been carried out on the antiosteoarthritic activities of polysaccharides, such as angelica polysaccharide, Achyranthes bidentata polysaccharide, and others. The specific mechanism of anti-OA is described in Section 3.

3.3. Polyphenols. Polyphenols are natural antioxidants that can reduce oxidative damage to lipids, proteins, enzymes, carbohydrates, and DNA in living cells and tissues. Resveratrol was found to stimulate endothelial production of nitric oxide, reduce oxidative stress, inhibit vascular inflammation, and prevent platelet aggregation [10]. Recent studies have found that some natural polyphenols have antiosteoarthritic effects such as epigallocatechin gallate, resveratrol, piceatannol, pterostilbene, and honokiol [11-15]. Their structures are shown in Figure 2. The specific mechanism of anti-OA is described in Section 3.

3.4. Flavonoids. Flavonoids are secondary metabolites that have an important anti-inflammatory role via reducing the activation of inflammatory bodies. The effects of quercetin on the inflammasome during fructose-induced hyperuricemia and dyslipidemia in rats were studied. It was found that quercetin improved renal inflammation and disease symptoms by reducing the renal expression of NLRP3 inflammasome components (such as NLRP3, ASC, and caspase-1) and reducing the levels of IL-1, IL-18, IL-6, and TNF- $\alpha$ in kidney and serum of fructose fed rats [16]. Flavonoids are widely found in fruits, vegetables, nuts, cereals, and so on [17]. Studies have found that flavonoids, such as biochanin A, astragalin, baicalin, kaempferol, apigenin, isorhamnetin, hesperidin, icariin, quercetin, pinocembrin, rutin, and bavachin, the chemical structures of which are shown in Figure 3, have therapeutic effects on OA. Their structures are shown in Figure 2. The specific mechanism of anti-OA is described in Section 3.

3.5. Alkaloids. Alkaloids, a type of natural components used widely in traditional Chinese medicine, regulate cell morphology, apoptosis, and autophagy to prevent and treat 
<smiles>OCC1=CC(O)C2C=COC(OC3OC(CO)C(O)C(O)C3O)C12</smiles>

Aucubin<smiles>C=CC1C2=CCOC(=O)C2=COC1OC1OC(CO)C(O)C(O)C1O</smiles>

Gentiopicroside<smiles>CC(C)C1=CC2=CCC3CC(CC(=O)O)CCC3C2CC1</smiles>

Abietic acid<smiles>O=C(O)C1=COC(OC2OC(CO)C(O)C(O)C2O)C2C1C=CC2(O)CO</smiles>

Monotropein<smiles>C=C1CC(C)(CO)C2CC(O)CCC2C1CC=C1C(=O)OCC1O</smiles>

Andrographolide<smiles>CC1C(O)C(=O)CC2C1CCC1C2(C)CCC2(C)C1(C)CCC1(C)CCC(C)(C(=O)O)CC12C</smiles>

Celastrol

FIGURE 1: Structural formula of terpenoids with antiosteoarthritis effects from natural products.<smiles>O=C(OC1Cc2c(O)cc(O)cc2OC1c1cc(O)c(O)c(O)c1)c1cc(O)c(O)c(O)c1</smiles>

Epigallocatechin gallate<smiles>Oc1ccc(/C=C/c2ccc(O)cc2O)cc1</smiles>

Resveratrol<smiles>Oc1ccc(C=Cc2ccc(O)c(O)c2)c(O)c1</smiles>

Piceatannol<smiles>COc1cc(/C=C/c2ccc(O)cc2)cc(OC)c1</smiles>

Pterostilbene<smiles>C=CCc1ccc(O)c(-c2ccc(O)c(CC=C)c2)c1</smiles>

FIGURE 2: Structural formula of polyphenols with antiosteoarthritis effects from natural products.

cancer. For example, matrine-induced stress destroyed the proliferation and migration of HepG2 cells. In addition, matrine promotes apoptosis of hepatoma cells, which is related to extracellular signal regulated kinase (ERK). In addition, lycorine treatment can also significantly reduce cell viability by inducing HCC cell cycle arrest in G2/M phase and reducing the expression of cyclin $\mathrm{A}, \mathrm{B} 1, \mathrm{C} 2$, and dependent kinase [18]. Sinomenine, nicotine, tetramethylpyrazine, and berberine, the structures of which are shown in Figure 4, are alkaloids that can relieve OA. The specific mechanism of anti-OA is described in Section 3.

3.6. Saponins. Saponins are natural glycosides that possess neuroprotective effect. Ginsenoside Rd has a protective effect on focal cerebral ischemia in aged mice, which may be related to the weakening of redox imbalance. Ginsenoside Rd has the characteristics of penetrating the complete blood-brain barrier 
<smiles>COc1ccc(-c2coc3cc(O)cc(O)c3c2=O)cc1</smiles><smiles>O=c1cc(-c2ccc(O)cc2O)oc2cc(O)cc(O)c12</smiles>

Kaempferol<smiles>COc1ccc(C2CC(=O)c3c(O)cc(OC4OC(COC5OC(C)C(O)C(O)C5O)C(O)C(O)C4O)cc3O2)cc1O</smiles>

Hesperidin<smiles>O=C1CC(C2CCCCC2)Oc2cc(O)cc(O)c21</smiles>

Pinocembrin<smiles>O=c1c(OC2OC(CO)C(O)C(O)C2O)c(-c2ccc(O)cc2)oc2cc(O)cc(O)c12</smiles>

Astragalin<smiles>O=c1cc(-c2ccc(O)cc2)oc2cc(O)cc(O)c12</smiles>

Apigenin<smiles>COc1ccc(C2Oc3c(CC=C(C)C)c(OC4OC(CO)C(O)C(O)C4O)cc(O)c3C(=O)C2OC2OC(C)C(O)C(O)C2O)cc1</smiles>

Icarrin<smiles>CC1OC(OCC2OC(Oc3c(-c4ccc(O)c(O)c4)oc4cc(O)cc(O)c4c3=O)C(O)C(O)C2O)C(O)C(O)C1O</smiles>

Rutin<smiles>O=C(O)C1CC(Oc2cc3oc(-c4ccccc4)cc(=O)c3c(O)c2O)C(O)C(O)C1O</smiles>

Baicalin<smiles>COc1cc(-c2oc3cc(O)cc(O)c3c(=O)c2O)ccc1O</smiles>

Isorhamnetin<smiles>O=c1c(O)c(-c2ccc(O)c(O)c2)oc2cc(O)cc(O)c12</smiles>

Quercetin

FIGURE 3: Structural formula of flavonoids with antiosteoarthritis effects from natural products.

and has a protective effect on transient and permanent middle cerebral artery occlusion in the rat experimental stroke model. Ginsenoside Rd has been shown to partially improve neurological deficits in patients with acute ischemic stroke in a multicenter, randomized, double-blind, placebo-controlled phase II trial $[19,20]$. Saponins found in some traditional Chinese medicinal plants, such as Achyranthes bidentata, Panax ginseng, Gynostemma pentaphyllum, Polygala tenuifolia, and Hedera helix, have antiosteoarthritic effects [21-25]. The specific mechanism of anti-OA is described in Section 3.

3.7. Others. Natural pigments, such as delphinidin, astaxanthin, and shikonin, have also been found to relieve OA in recent years. In addition, quinones and phenolic acids found in Salvia miltiorrhiza were found to be beneficial in treating OA [26]. Schisandrin is a lignan that can also relieve OA [27]. Coumarins, such as psoralen and bergapten, also have antiosteoarthritic activities [28, 29]. Polyoxypregnane glucosides and $\alpha$-bisabolol are also natural products with comparable efficacy in $\mathrm{OA}[30,31]$. Their structures are shown in Figure 5.

\section{Mechanisms of Action of Natural Products in OA Treatment}

OA is accompanied by inflammatory response and inflammation is usually associated with mitochondrial damage. Production of reactive oxygen species (ROS) after 


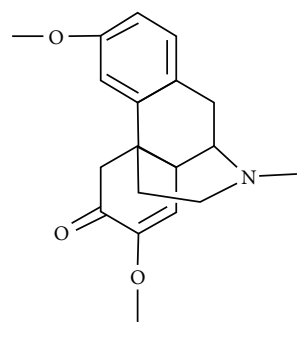

Sinomenine

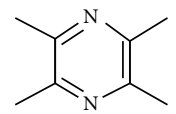

Ligustrazine

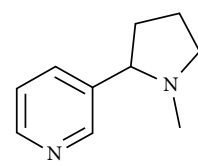

Nicotine

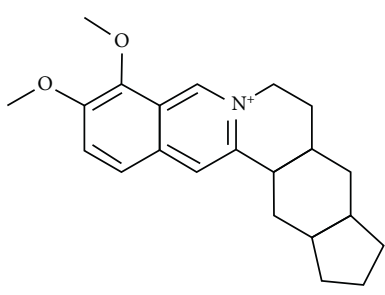

Berberine

FIGURE 4: Structural formula of alkaloids with antiosteoarthritis effects from natural products.

mitochondrial injury promotes mitochondrial autophagy and leads to abnormal cell function. After chondrocyte injury, the increased secretion of matrix metalloproteinases (MMPs) and disintegrin and metalloproteinase with thrombospondin motifs (ADAMTS) leads to ECM degradation, promotes chondrocyte apoptosis, and accelerates the process of OA. The decrease of chondrocytes leads to further degradation of articular cartilage and the production of MMPs, synovial angiogenesis, and inflammatory factors and promotes further destruction of cartilage.

The effects of natural products on OA are mainly concentrated in chondrocytes. They can improve cytokine content and signaling pathways in chondrocytes, resulting in the reduction in the production of inflammatory factors, reduction in oxidative stress, regulation of chondrocyte metabolism, promotion of chondrocyte proliferation, or inhibition of chondrocyte apoptosis. In the following sections, the therapeutic effects of natural products on OA are presented in detail.

4.1. Reduction of the Production of Inflammatory Factors. Inflammatory factors promote OA by affecting the normal physiological functions of chondrocytes. The accumulation of inflammatory factors such as IL- $1 \beta$, TNF- $\alpha$, NO, PGE2, and COX-2 can induce the production of more $\mathrm{NO}$ by chondrocytes and damage the mitochondrial respiratory chain, leading to apoptosis and degradation of the ECM of chondrocytes. Reducing the production of these inflammatory components is conducive for normal chondrocyte growth [2].

4.1.1. Terpenoids. Aucubin is an iridoid compound found in Eucommia ulmoides, Plantago asiatica, and Rehmannia glutinosa. It is the main active component of these plants and has anti-inflammatory, antioxidant, and liver protection functions. In $\mathrm{H}_{2} \mathrm{O}_{2}$-treated chondrocytes, aucubin reduced

cell damage [32]. Abietic acid, the main component of Colophonium, can elicit an anti-inflammatory action by inhibiting the nuclear transcription factor-kappa B (NF- $\kappa \mathrm{B})$ and mitogen-activated protein kinase (MAPK) signaling pathways [33].

4.1.2. Polysaccharides and Polyphenols. Angelica sinensis polysaccharides can prevent chondrocyte apoptosis and suppress the gene expression of inflammatory factors such as IL-1 $\beta$ and TNF- $\alpha$ [34]. Leong et al. found that Epigallocatechin gallate combined with avocado soybean unsaponifiables could mitigate OA [35]. In addition, honokiol can suppress the IL-1b-triggered activation of the IkappaB kinase (IKK)/I-kappa-B-alpha $(\mathrm{IkB} \alpha) / \mathrm{NF}-\mathrm{kB}$ signaling pathway and elicit anti-inflammatory effects [36].

4.1.3. Flavonoids. Biochanin A, which is similar to estradiol, can bind to estrogen receptors and reduce cartilage ECM degradation through its anti-inflammatory effects [37]. Baicalin and astragaloside are natural saponins. Baicalin reduces inflammatory injury through the downregulation of miR-126, thereby blocking the activation of the $\mathrm{NF}-\kappa \mathrm{B}$ signaling pathway [38].

4.1.4. Alkaloids and Saponins. Sinomenine, isolated from Sinomenium acutum, is commonly used in the treatment of rheumatism. Wu et al. $[39,40]$ found that sinomenine, as well as resveratrol, can reduce the production of inflammatory factors via nuclear factor E2-related factor 2(Nrf2)/ heme oxygenase $1(\mathrm{HO}-1)$ and $\mathrm{NF}-\kappa \mathrm{B}$ signaling. Nicotine is an effective acetylcholine receptor agonist, but has no clinical application value at present. The expression of IL-6 and IL- $1 \beta$ was found to be inhibited by nicotine in the chondrocytes of OA patients [41]. Astragaloside treats OA through its anti-inflammatory and antiapoptosis effects [42].

4.1.5. Others. Salvia miltiorrhiza contains water-soluble and lipid-soluble components. The lipid-soluble components tanshinone IIA and salvianolic acid B have similar effects in reducing inflammatory factors $[43,44]$. Astaxanthin is a carotenoid with strong antioxidant effects. When combined with hyaluronic acid and krill oil, it can reduce inflammatory reaction [45]. Delphinidin, one of the six main monomer forms of anthocyanins, has a suppressive action on the expression of COX- 2 by inducing the production IL- $1 \beta$ and PGE2 and activating the NF- $\kappa \mathrm{B}$ signaling pathway [46].

Bergapten, widely found in fruits, limits the progression of OA by regulating the acidic leucine-rich nuclear phosphoprotein-32A (ANP32A)/ataxia-telangiectasia mutated (ATM) signaling pathway [47]. $\alpha$-Bisabolol has a variety of biological activities, one of which is anti-inflammation, elicited by blockage of the NF- $\kappa \mathrm{B}, \mathrm{p} 38$, and c-Jun N-terminal kinase (JNK) signaling pathways [48].

4.2. Reduction of Oxidative Stress. Excessive oxygen free radicals in the joint accelerate the oxidative stress reaction, 
<smiles>Oc1cc(O)c2ccc(-c3cc(O)c(O)c(O)c3)[o+]c2c1</smiles>

Delphinidin<smiles>CC(C)=CCC(O)C1CC(=O)c2c(O)ccc(O)c2C1=O</smiles>

Shikonin<smiles>CC1=C(/C=C/C(C)=C/C=C/C(C)=C/C=C/C=C(C)/C=C/C=C(C)/C=C/C2=C(C)C(=O)C(O)CC2(C)C)C(C)(C)CC(O)C1=O</smiles>

Astaxanthin<smiles>Cc1coc2c1C(=O)C(=O)c1c-2ccc2c(C)cccc12</smiles>

Tanshinone I<smiles>Cc1coc2c1C(=O)C(=O)c1c-2ccc2c1CCCC2(C)C</smiles>

Tanshinone IIA<smiles>C=C(/C=C/c1ccc(O)c2c1C(C(=O)OC(Cc1ccc(O)c(O)c1)C(=O)O)C(c1ccc(O)c(O)c1)O2)OC(Cc1ccc(O)c(O)c1)C(=O)O</smiles>

Salvianolic acid B<smiles>O=C(O)c1cc(O)c(O)c(O)c1</smiles>

Gallic acid<smiles>COc1c2ccoc2cc2oc(=O)ccc12</smiles>

Bergapten<smiles>O=c1ccc2cc3ccoc3cc2o1</smiles>

Psoralen<smiles>COc1cc2c(c(OC)c1OC)-c1c(cc(OC)c(OC)c1OC)CC(C)C(C)C2</smiles>

Schizandrin A

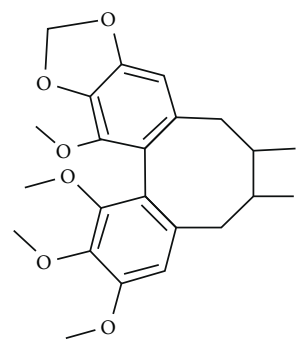

Schizandrin B<smiles>CCCCCC(C)(C)C1CC=C(C)CC1</smiles>

FIgURE 5: Structural formula of others with antiosteoarthritis effects from natural products. resulting in serious damage to chondrocytes and the ECM, thus favoring the advancement of OA. Malondialdehyde (MDA) and superoxide dismutase (SOD) are two important indicators for the measurement of the oxidative stress response. They participate in the intracellular signal transduction mechanism. Once there is an imbalance in their concentrations, the oxidative stress response is aggravated.

4.2.1. Terpenoids and Polysaccharides. Andrographolide has antioxidant and free radical scavenging effects related to the Keap1-Nrf2-antioxidant response element (ARE) signal pathway [49]. In addition, Ajeeshkumar et al. [50] found that the proteoglycan extracted from thorn shark cartilage could maintain the activity of SOD in an OA rat model.

4.2.2. Polyphenols. Wen et al. [51] found that gallic acid can reduce ROS content and increase SOD content in rabbit chondrocytes exposed to AGEs. In addition, pterostilbene attenuates ROS production in the mitochondria and cytoplasm of IL-1 $\beta$-induced chondrocytes [52].

4.2.3. Flavonoids. Pan et al. [53] found that baicalin can reduce oxidative stress and apoptosis in endplate$\mathrm{H}_{2} \mathrm{O}_{2}$-induced chondrocytes. In another study, kaempferol, 
apigenin, and synovial membrane derived stem cells (SMMSCs) injected into the joints of OA rats increased SOD levels in the cartilage homogenate and decreased MDA levels [54]. In addition, Zhou et al. [55] found that isorhamnetin can reduce ROS production induced by RANKL and protect chondrocytes from oxidative stress, which leads to apoptosis. Hesperidin, a dihydroflavone glycoside found in the pericarp of Citrus limon and mandarin orange, inhibits oxidative stress in $\mathrm{H} 2 \mathrm{O} 2$-induced rat chondrocytes [56].

4.2.4. Alkaloids, Saponins, and Others. Ligustrazine is the main active component in Ligusticum chuanxiong rhizomes. In IL- $1 \beta$-induced chondrocytes, ligustrazine has anti-inflammatory and antioxidant effects, regulating SOX9 concentration and the NF- $\kappa \mathrm{B}$ signaling pathway [57]. Advanced glycation end products (AGEs) can induce physiological and pathological reactions in cells. $\mathrm{Xu}$ et al. [58] found that Hederacoside- $\mathrm{C}$ can downregulate oxidative stress in OA. Lee et al. [59] observed that delphinidin could activate the Nrf2 signaling pathway, promote autophagy of chondrocytes, and protect them against oxidative stress.

4.3. Regulation of Chondrocyte Metabolism. Abnormal metabolism in chondrocytes, which is characterized by damage to the cartilage ECM, including the degradation of proteoglycan and collagen, can also promote or aggravate OA. Overexpression of MMPs and ADAMTS can lead to the degradation of proteoglycan and collagen. However, the tissue inhibitor of metalloproteinase (TIMP) can inhibit the activity and reduce the degradation of proteoglycan.

4.3.1. Polyphenols and Alkaloids. Tang et al. [60] found that piceatannol, found in a number of food items, inhibited IL$1 \beta$-induced $\mathrm{NF}-\kappa \mathrm{B}$ activation by activating the $\mathrm{Nrf} 2 / \mathrm{HO}-1$ pathway. Teng et al. [61] found that nicotine can activate the phosphatidylinositide 3-kinase (PI3K)/Akt and inhibit the $\mathrm{NF}-\kappa \mathrm{B}$ signaling pathways in OA animal models. Berberine can promote cell survival and matrix production through the activation of the Akt/p70S6K/S6 signaling pathway [62].

4.3.2. Flavonoids. Quercetin is widely distributed in the plant kingdom and has anti-inflammatory, antiviral, and antitumor pharmacological activities. It can maintain the integrity of the ECM of articular cartilage [63-65]. Chen et al. [66] showed that baicalin can reduce cartilage destruction. The TCM "Morinda officinalis" is the dried root of Morinda officinalis. Its iridoid component, Monotropein, can significantly reduce the gene expression of MMP-3 and MMP-13 in IL-1 $\beta$-induced chondrocytes [67]. Zhang et al. [68] found that pinocembrin also acts on the ECM by blocking NF-kB signaling pathway. Wu et al. [69] found that at the mRNA and protein levels, Biochanin A can downregulate the expression of MMPs, upregulate the expression of TIMP-1, and block the NK- $\kappa \mathrm{B}$ signaling pathway. Bavachin, a phytoestrogen, can promote the effective synthesis and antidecomposition of ECM [70].
4.3.3. Saponins. Icariin, an extract from dried stems and leaves of Epimedium, can inhibit the $\mathrm{p} 38$, JNK, and $\beta$-catenin signaling pathways in IL- $1 \beta$-induced chondrosarcoma SW1353 cells and OA rat models [71]. Gentiopicroside is the main active component of Gentianaceae plants. It can enhance MAPK signaling pathways that prevent P38, extracellular regulated kinases (ERK), and JNK phosphorylation [72]. Panax ginseng contains a variety of saponins. Ginsenoside $\mathrm{Rg} 1$ can reduce the degradation of proteoglycan and type II collagen [73]. Other studies have found that gypenoside reduces the activation of signaling pathways, thus protecting cartilage [74]. Tenuigenin, found in Polygala tenuifolia, also suppresses the expression of IL- $1 \beta$-induced MMP-1, MMP-3, and MMP-13 [75].

4.3.4. Others. Schisandra chinensis contains many kinds of lignans, including schisandrin A and schisandrin B. In OA treatment, schisandrin B and schisandrin A have similar pharmacological effects. They can inhibit the production of MMPs and ADAMTS- 5 in IL- $1 \beta$-induced chondrocytes and upregulate the gene expression of type II collagen and proteoglycan [76]. Furthermore, Astaxanthin, which targets the chondrocyte matrix, is a potential therapeutic drug for OA [77]. Furthermore, Tanshinone I can reduce the degradation of type II collagen and proteoglycan, upregulate the gene expression of (SRY)-related high-mobility group (HMG) box 11 (SOX11), downregulate the gene expression of MMP-13, and suppress the p-NF- $\kappa \mathrm{B}$ signaling pathway, reducing cartilage damage [78].

Shikonin is the main active component of Lithospermum erythrorhizon. It can adjust the equilibrium between the synthesis and degradation of cartilage [79]. Moreover, the polyoxypregnane glycoside from Dregea volubilis extracts may inhibit cartilage degradation in OA and may be used as a nutritive substance for maintaining joint integrity and function [80]. Psoralen, which has estrogen-like effects, protects chondrocytes and reduces the gene expression of MMPs and ILs [81].

4.4. Promotion of Chondrocyte Proliferation or Inhibition of Apoptosis. One of the characteristics of OA is chondrocyte apoptosis. Many genes and signaling pathways in the joint can affect the proliferation and apoptosis of chondrocytes. Once these genes and signaling pathways are abnormally expressed, they inhibit the proliferation of chondrocytes and promote their apoptosis. While autophagy can help in maintaining the normal physiological state of chondrocytes, its reduction can also promote injury to chondrocytes. Bone marrow mesenchymal stem cells have strong differentiation abilities and can be induced to differentiate into chondrocytes in specific environments conducive for cartilage reconstruction [82].

4.4.1. Terpenoids. In IL- $1 \beta$-induced chondrocytes, aucubin elicits its action by inhibiting chondrocyte apoptosis [83]. Celastrol, which can be extracted from Celastrus orbiculatus, Tripterygium wilfordii, and other plants, can block the NF- 
$\kappa \mathrm{B}$ signaling pathway in vivo and in vitro, strengthening chondrocyte autophagy and increasing resistance to apoptosis. Resveratrol also has the same effect $[84,85]$.

4.4.2. Polysaccharides. Yu et al. have found that polysaccharides in Radix Achyranthis Bidentatae can significantly upregulate the gene expression of Wnt-4, frizzled-2, and $\beta$-catenin, downregulate the gene expression of GSK- $3 \beta$, promote the nuclear translocation of $\beta$-catenin, and activate the Wnt/ $\beta$-catenin signaling pathway $[86,87]$. Polysaccharides from Cibotium barometz can promote the transition of chondrocytes from the G1 to the S phase [88].

4.4.3. Flavonoids. Rutin, a quercetin glycoside derivative, can block these signaling pathways in $\mathrm{H}_{2} \mathrm{O}_{2}$-treated chondrocytes [89]. In addition, astragalin elicits antiapoptotic effects by mediating the autophagy of chondrocytes [90].

4.4.4. Alkaloids. Furthermore, berberine, found in Rhizoma Coptidis, can promote the proliferation of chondrocytes in vitro and activate the $\mathrm{Wnt} / \beta$-catenin signaling pathway [91]. Zheng et al. [92] found that nicotine reduces chondrocyte apoptosis by activating the PI3K/Akt signaling pathway in IL- $1 \beta$-induced chondrocytes.

4.4.5. Saponins and Others. Triterpenoid saponins isolated from Achyranthes bidentate have significant effects on IL-1binduced apoptosis [93]. Activation of p-ERK, MAPK, and $\mathrm{p}$-JNK is associated with chondrocyte apoptosis. Additionally, Zheng et al. [94] found that the Wnt/ $\beta$-catenin signaling pathway, which can be activated by psoralen, can promote chondrocyte proliferation.

\section{Discussion}

At present, the complexity of $\mathrm{OA}$, which has no cure, is still not fully understood. In recent years, integrated genomics, proteomics, metabolics, and bioelectronics were used to explore OA chondrocytes [95]. Losing weight and practicing sporting activities can improve joint pain and function in OA patients. Oral and topical NSAIDs are the most common treatment for OA. Intra-articular injection of corticosteroids and hyaluronic acid is also used [96]. The etiology of OA is very complex, involving many targets, and the current drug treatment, though accompanied by many side effects, can only relieve pain. Natural products have lesser side effects and act on multiple targets, and, thus, have increasingly attracted the attention of researchers. The treatment of OA is highly beneficial, as it improves the quality of life of the patient and reduces the national economic burden.

Western medicine is mainly employed in the clinical treatment of OA [97]. Natural products have a long history of consumption in China, and there are few toxic reactions, but some also have serious toxic effects. However, the research on the efficacy of traditional Chinese medicine is slow, and now it needs more in-depth research. Natural products are worth exploring for future use. For this, we need to understand the interaction between natural products and the relationship between corresponding targets and signaling pathways. Many natural products have shown potential for use in treating $\mathrm{OA}$ in vivo and in vitro, but there is a lack of preclinical and clinical trial data. More work is needed to gradually move candidate natural products to clinical trials, so that more patients can benefit directly [5].

In this review, we summarized the literature on the antiosteoarthritic effects of natural products in the last decade. We comprehensively introduced 62 published papers on 48 natural products involving $6,3,5,12,4$, and 5 kinds of terpenoids, polysaccharides, polyphenols, flavonoids, alkaloids, and saponins, respectively (and others). Research mainly focused on flavonoids, terpenoids, polyphenol, polysaccharides, alkaloids, and saponins. We summarize these natural products according to the structural classification, which are shown in Tables 1-7. We found that some natural products, such as baicalin, apigenin, icariin, quercetin, nicotine, and berberine, are studied more often than others. However, there are few available data for some natural products, such as polyoxypregnane glucoside, $\alpha$-bisabolol, and saponins. Animal and cell models of OA are shown in Figure 6. Signaling pathways are involved in the antiosteoarthritic action of natural products (Figure 6). Most natural products are associated with the NF- $\kappa \mathrm{B}$ and $\mathrm{Wnt} /$ $\beta$-catenin signaling pathways. This article summarizes four aspects (inflammatory factors, oxidative stress, cell metabolism, and cell survival) to explain the antiosteoarthritic effects of natural products. A natural product may have multiple mechanisms in its antiosteoarthritic action. Different mechanisms are also interrelated; an increase in inflammatory factors will lead to the synthesis of MMPs, which will lead to cartilage tissue degradation. This study involved a variety of factors and signaling pathways, mainly TNF- $\alpha$, IL$1 \beta, \mathrm{MDA}, \mathrm{SOD}, \mathrm{ROS}, \mathrm{NF}-\kappa \mathrm{B}, \mathrm{Nrf} 2 / \mathrm{HO}-1, \mathrm{PI} 3 \mathrm{~K} / \mathrm{Akt}$, and $\mathrm{Wnt} / \beta$-catenin. In summary, the pathogenesis of $\mathrm{OA}$ is complex, involving multiple factors, pathways, and mechanisms of pathological changes, which directly or indirectly lead to ECM degradation, cartilage damage, and subchondral bone hyperplasia. These factors and signaling pathways do not exist in isolation, but have interlocked and interlaced relationships. In conclusion, the potential therapeutic effects of natural products in OA are the result of multichannel and multitarget mechanisms, which need to be further investigated.

Due to the complex pathological nature of OA, its drug treatment is only symptomatic. We should look for effective anti-OA products from the natural products, using modern pharmacological methods to understand their mechanism of action, then screen for effective monomer components, and accumulate effective candidate drugs for the treatment of OA, which has important value for the development of the drug treatment for OA. Furthermore, researchers will continue to explore the mechanism of $\mathrm{OA}$ in the future, Whether the two studies can reach a synchronous level is a realistic problem we are facing. Therefore, the combination of research on the mechanism of $\mathrm{OA}$ and research on natural products is an important direction for future research. The association of natural products may produce 
TABLE 1: Natural products of terpenoids with antiosteoarthritis function.

\begin{tabular}{|c|c|c|c|c|}
\hline Compound & Source & Cell/animal model & Effect & Ref \\
\hline Aucubin & $\begin{array}{l}\text { Eucommia ulmoides, } \\
\text { Plantago asiatica, } \\
\text { Rehmannia glutinosa }\end{array}$ & $\begin{array}{c}\text { IL- } 1 \beta \text {-induced porcine } \\
\text { chondrocytes/chondrocytes of } \\
\text { male C57BL/6 mice induced by } \\
\text { DMM }\end{array}$ & $\begin{array}{l}\text { Maintain ACAN and COL2A1 gene } \\
\text { expressions, prevent IL- } 6 \text { and MMP-13 gene } \\
\text { upregulation, reduce the caspase- } 3 \text { activity, and } \\
\text { downregulate Bax, caspase- } 9 \text { and caspase-3 } \\
\text { Inhibited IL- } 1 \beta \text {-induced TNF- } \alpha \text {, NO, PGE2 }\end{array}$ & [32] \\
\hline Abietic acid & Colophonium & Human OA chondrocytes & $\begin{array}{l}\text { production, and COX- } 2 \text { expression, suppressed } \\
\text { MMP-1, MMP-3, and MMP-13 production }\end{array}$ & [33] \\
\hline Andrographolide & Andrographis paniculata & $\begin{array}{l}\text { Chondrocytes of } \mathrm{SD} \text { rats induced } \\
\text { by } \mathrm{H}_{2} \mathrm{O}_{2}\end{array}$ & $\begin{array}{l}\text { Upregulate expression of SOD and decrease } \\
\text { MDA activity, MMP-13, TIMP- } 1 \text {, and Il-6 } \\
\text { Ameliorate IL- } 1 \beta \text {-induced chondrocyte }\end{array}$ & [49] \\
\hline Celastrol & $\begin{array}{l}\text { Celastrus orbiculatus, } \\
\text { Tripterygium wilfordii }\end{array}$ & $\begin{array}{c}\text { Chondrocytes of SD rats/male SD } \\
\text { rats induced by ACLT }\end{array}$ & $\begin{array}{l}\text { apoptosis and increased the expression of LC3- } \\
\text { II and Beclin- } 1 \text { and, moreover, decrease the } \\
\text { phosphorylation degree of I } \kappa \mathrm{B} \alpha \text { and P65 }\end{array}$ & [84] \\
\hline
\end{tabular}

DMM: destabilization of medial meniscus; ACLT: anterior cruciate ligament.

TABLE 2: Natural products of polysaccharides with antiosteoarthritis function.

\begin{tabular}{|c|c|c|c|c|}
\hline Compound & Source & Cell/animal model & Effect & Ref \\
\hline $\begin{array}{l}\text { Angelica sinensis } \\
\text { polysaccharide }\end{array}$ & Angelica sinensis & $\begin{array}{l}\text { Chondrocytes of male } \\
\text { SD rats }\end{array}$ & $\begin{array}{l}\text { Inhibit both apoptosis and expression of inflammatory } \\
\text { cytokines (IL-1 } \beta \text { and TNF- } \alpha \text { ), increase expression of } \\
\text { anabolic gene (Col2a1, aggrecan, and SOX9), and decrease } \\
\text { expression of catabolic gene (MMP-1, }-3 \text {, and -9) }\end{array}$ & {$[34]$} \\
\hline $\begin{array}{l}\text { Cartilage proteoglycan } \\
\text { of the thorn shark }\end{array}$ & $\begin{array}{l}\text { Cartilage of } \\
\text { Centrophorus }\end{array}$ & $\begin{array}{l}\text { Female Wistar rats } \\
\text { induced by MIA }\end{array}$ & $\begin{array}{l}\text { Reduce the expressions of the inflammatory modulators } \\
\text { including TNF- } \alpha \text {, IL- } 1 \beta \text {, MMP-13, NOS2, IL-10, and } \\
\text { COX-2 }\end{array}$ & {$[50]$} \\
\hline $\begin{array}{l}\text { Achyranthes bidentata } \\
\text { polysaccharide }\end{array}$ & $\begin{array}{c}\text { Radix Cyathulae } \\
\text { Bidentatae }\end{array}$ & $\begin{array}{l}\text { Chondrocytes of male } \\
\text { SD rats }\end{array}$ & $\begin{array}{c}\text { Upregulate gene expression of cyclin D1, CDK4, and } \\
\text { CDK6 and suppress NFATc1 transcriptional activity and } \\
\text { the phosphorylation of MAPK pathways }\end{array}$ & {$[86,87]$} \\
\hline $\begin{array}{l}\text { Cibotium barometz } \\
\text { polysaccharides }\end{array}$ & $\begin{array}{l}\text { Cibotium } \\
\text { barometz }\end{array}$ & $\begin{array}{l}\text { Chondrocytes of male } \\
\text { SD rats }\end{array}$ & $\begin{array}{l}\text { Boost the mRNA and protein expression of cyclin D1, } \\
\text { CDK4, and pRB }\end{array}$ & [88] \\
\hline
\end{tabular}

MIA: injection of sodium iodoacetate.

TABLE 3: Natural products of polyphenols with antiosteoarthritis function.

\begin{tabular}{|c|c|c|c|c|}
\hline Compound & Source & Cell/animal model & Effect & Ref \\
\hline $\begin{array}{l}\text { Epigallocatechin } \\
\text { gallate }\end{array}$ & Camellia sinensis & $\begin{array}{l}\text { Horse chondrocytes induced by } \\
\text { TNF- } \alpha \text { and IL- } 1 \beta\end{array}$ & Reduce the content of COX-2, PGE2 & [35] \\
\hline Honokiol & Magnolia officinalis & $\begin{array}{l}\text { Human OA chondrocytes induced } \\
\text { by IL- } 1 \beta\end{array}$ & $\begin{array}{l}\text { Inhibit expression/production of IL-6, COX- } \\
\text { 2/PGE2, and iNOS/NO }\end{array}$ & [36] \\
\hline Resveratrol & $\begin{array}{l}\text { Vitis vinifera, Arachis } \\
\text { hypogaea, and Fructus } \\
\text { Mori }\end{array}$ & $\begin{array}{c}\text { Male C57BL/6 mice/chondrocytes } \\
\text { of mice }\end{array}$ & $\begin{array}{c}\text { Inhibit IL- } 1 \beta \text {, IL- } 6 \text {, and IL-18 expression } \\
\text { levels, decrease caspase-3/9 activity, and } \\
\text { stimulate HO-1/Nrf- } 2 \text { signaling }\end{array}$ & {$[40,85]$} \\
\hline Gallic acid & $\begin{array}{l}\text { Cornus officinalis, } \\
\text { Rheum palmatum, } \\
\text { Punica granatum }\end{array}$ & $\begin{array}{c}\text { Chondrocytes of male New Zealand } \\
\text { rabbits }\end{array}$ & $\begin{array}{l}\text { Decrease the content of ROS and increase the } \\
\text { content of SOD }\end{array}$ & {$[51]$} \\
\hline Pterostilbene & $\begin{array}{l}\text { Semen Trigonellae, } \\
\text { Vitis vinifera }\end{array}$ & Chondrocytes of SD rats & $\begin{array}{c}\text { Inhibit the level of COX-2, iNOS, PGE } 2 \text {, and } \\
\text { NO, prevent cartilage degeneration, and } \\
\text { promot the nuclear translocation of Nrf } 2 \text { in } \\
\text { cartilage }\end{array}$ & {$[52]$} \\
\hline Piceatannol & $\begin{array}{l}\text { Seeds of Euphorbia } \\
\text { lagascae }\end{array}$ & $\begin{array}{l}\text { Human OA chondrocytes induced } \\
\text { by IL- } 1 \beta / \mathrm{C} 57 \mathrm{BL} / 6 \text { male wild-type } \\
\text { (WT) mice induced by DMM }\end{array}$ & $\begin{array}{c}\text { Attenuated cartilage degeneration and } \\
\text { reduced type II collagen loss and MMP-13 } \\
\text { levels }\end{array}$ & {$[61]$} \\
\hline
\end{tabular}

DMM: destabilization of medial meniscus.

synergism, reduce activity, and restrict detoxification. This provides a new direction for the future research of natural products.
A single ingredient is used in western medicine, and the natural product is also a single ingredient. They may have toxic and side effects. Acetaminophen and nonsteroidal anti- 


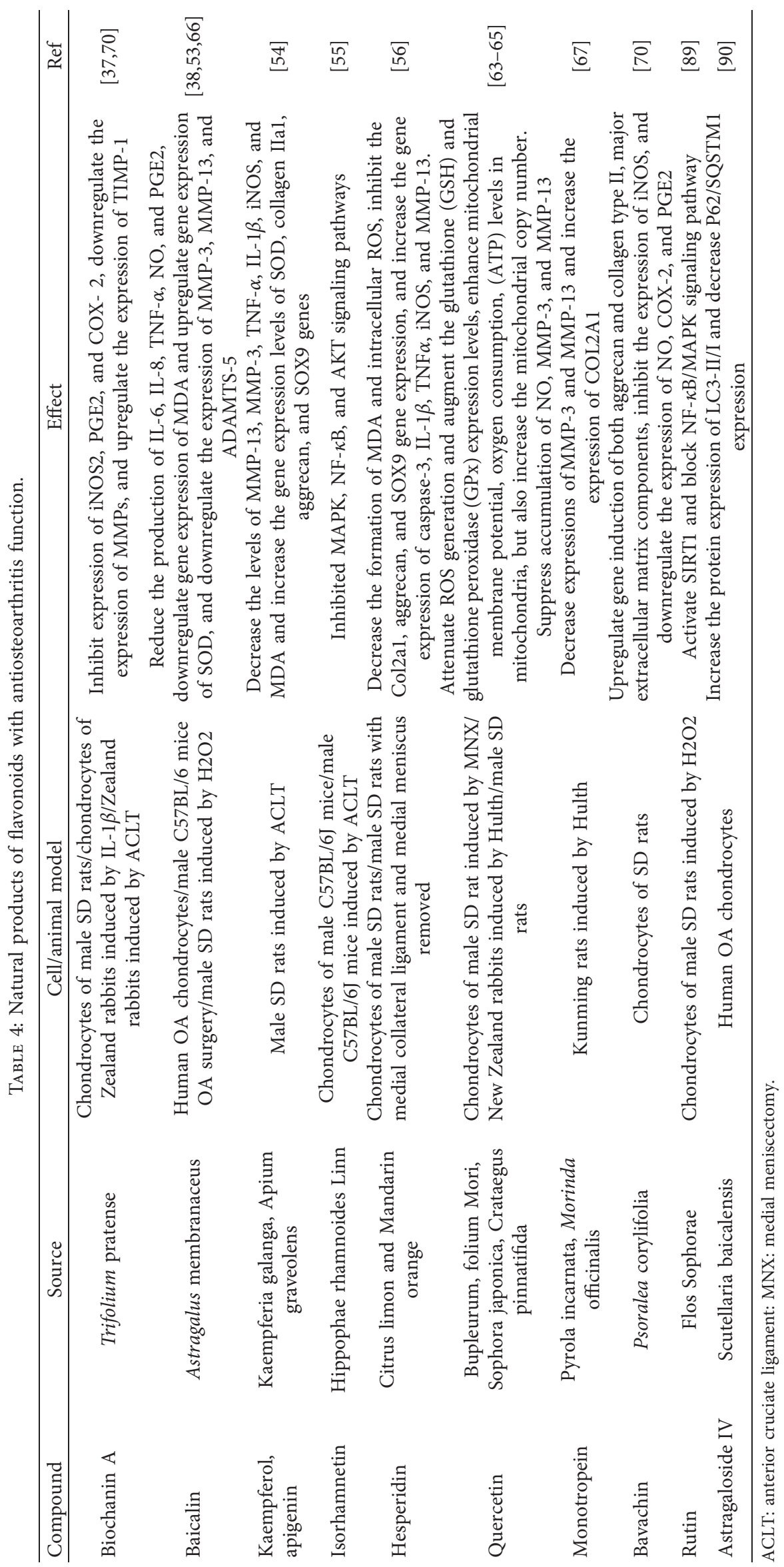


TABLE 5: Natural products of alkaloids with antiosteoarthritis function.

\begin{tabular}{|c|c|c|c|c|}
\hline Compound & Source & Cell/animal model & Effect & Ref \\
\hline Sinomenine & Sinomenium acutum & $\begin{array}{c}\text { Chondrocytes of C57BL/ } 6 \text { mice induced by } \\
\text { IL- } 6 \text { and IL-1 } \beta\end{array}$ & $\begin{array}{l}\text { Downregulate gene expression of iNOS, } \\
\text { COX-2, NO, PGE2, TNF }-\alpha \text {, activate the } \\
\text { nrf2/HO- } 1 \text { signaling pathways, and inhibit } \\
\text { NF- } \kappa \text { B activity }\end{array}$ & [39] \\
\hline Nicotine & $\begin{array}{l}\text { Nicotiana tabacum, } \\
\text { Solanum } \\
\text { lycopersicum, Lycium }\end{array}$ & $\begin{array}{l}\text { Chondrocytes of OA patients/a7-nAChR } \\
\text { mice induced by MIA/RAW } 264.7 \text { cells } \\
\text { induced by LPS/chondrocytes of male SD } \\
\text { rats induced by IL- } 1 \beta\end{array}$ & $\begin{array}{l}\text { Downregulate gene expression of IL- } 6 \text { and } \\
\text { IL- } 1 \beta \text {, downregulate the expression of } \\
\text { MMP-9, and increase the protein level of } \\
\text { Bcl- } 2 \text { and Bcl-xL }\end{array}$ & {$[41,61,92]$} \\
\hline Ligustrazine & $\begin{array}{l}\text { Rhizome of Ligusticum } \\
\text { chuanxiong }\end{array}$ & Human OA chondrocytes & $\begin{array}{c}\text { Increase SOD level, decrease ROS } \\
\text { production and decrease MDA level, } \\
\text { increase SOD level, decrease ROS } \\
\text { production and decrease MDA level, } \\
\text { increase SOX9 expression, and block NF- } \\
\kappa \mathrm{B} \text { pathway }\end{array}$ & [57] \\
\hline Berberine & Rhizoma coptidis & $\begin{array}{l}\text { Chondrocytes of male SD rats induced by } \\
\text { IL- } 1 \beta / \text { male SD rats induced by ACLT and } \\
\text { MMxs }\end{array}$ & $\begin{array}{l}\text { Downregulate expression of MMP-1, } \\
\text { MMP-3, MMP-13, and ADAMTS-5, } \\
\text { increase S phase cells, decrease G0/G1 } \\
\text { phase cells, upregulate } \beta \text {-catenin and } \\
\text { cyclin D1, and downregulate GSK-3 } \beta\end{array}$ & {$[62,91]$} \\
\hline
\end{tabular}

ACLT: anterior cruciate ligament; MMxs, resection of medial menisci.

TABLE 6: Natural products of saponins with antiosteoarthritis function.

\begin{tabular}{|c|c|c|c|c|}
\hline Compound & Source & Cell/animal model & Effect & Ref \\
\hline Astragaloside & $\begin{array}{l}\text { Astragalus } \\
\text { membranaceus }\end{array}$ & Chondrocytes of OA patient & $\begin{array}{c}\text { Inhibit IL-1b-induced production of } \\
\text { inflammatory factors, including IL-6, TNF-a, } \\
\text { NO, and PGE2, expression of MMP-13 and } \\
\text { ADAMTS-5, and the activation of NF- } \kappa \text { B } \\
\text { signaling and ameliorate the degeneration of } \\
\text { cartilage }\end{array}$ & {$[42]$} \\
\hline Hederacoside-C & $\begin{array}{l}\text { The leaves of Hedera } \\
\text { helix }\end{array}$ & $\begin{array}{l}\text { Chondrocytes of male C57BL/6J } \\
\text { mice }\end{array}$ & $\begin{array}{l}\text { Reduce AGE-induced increased levels of ROS } \\
\text { and suppress NF- } \kappa \text { B signaling pathway }\end{array}$ & {$[58]$} \\
\hline Pinocembrin & $\begin{array}{l}\text { Heartwood of Pinus } \\
\text { and Cerasus } \\
\text { pseudocerasus }\end{array}$ & Human OA chondrocytes & $\begin{array}{c}\text { Downregulate the expression of MMP-1, MMP- } \\
3 \text {, and MMP-13 and inhibit TNF-a-induced } \\
\text { phosphorylation and degradation of the NF- } \kappa \mathrm{B} \\
\text { inhibitor } \mathrm{I} \kappa \mathrm{B} \alpha\end{array}$ & {$[68]$} \\
\hline Icariin & $\begin{array}{l}\text { Epimedium brevicornu } \\
\text { Maxim }\end{array}$ & $\begin{array}{l}\text { SW1353 chondrosarcoma cells } \\
\text { induced by IL- } 1 \beta / \text { SD rats } \\
\text { induced by ACLT }\end{array}$ & $\begin{array}{c}\text { Downregulate the expression of MMP-13, reduce } \\
\text { levels of phosphorylated p38, phosphorylated } \\
\text { JNK, and } \beta \text {-catenin }\end{array}$ & {$[71]$} \\
\hline Gentiopicroside & Gentiana scabra Bunge & $\begin{array}{l}\text { Chondrocytes of male SD rats } \\
\text { induced by IL- } 1 \beta\end{array}$ & $\begin{array}{l}\text { Downregulate the expression of MMP-1, MMP- } \\
\text { 3, and MMP-13 and inhibit transduction of p38, } \\
\text { ERK, and JNK }\end{array}$ & {$[72]$} \\
\hline Ginsenoside Rg1 & Panax ginseng & $\begin{array}{l}\text { Human OA chondrocytes/male } \\
\text { SD rats induced by ACLT }\end{array}$ & $\begin{array}{l}\text { Inhibit IL- } 1 \beta \text {-induced chondrocyte gene and } \\
\text { protein expressions of MMP-13, COX-2, and } \\
\text { PGE2 and prevent type II collagen and aggrecan } \\
\text { degradation, attenuated cartilage degeneration, } \\
\text { and reduced type II collagen loss }\end{array}$ & {$[73]$} \\
\hline Gypenoside & $\begin{array}{l}\text { Gynostemma } \\
\text { pentaphyllum }\end{array}$ & $\begin{array}{l}\text { Human OA chondrocytes } \\
\text { induced by IL- } 1 \beta\end{array}$ & $\begin{array}{l}\text { Reduce MMP- } 3 \text { inhibited IL- } 1 \beta \text {-induced NO and } \\
\text { PGE2 production and MMP-13 expression and } \\
\text { suppress NF- } \kappa \beta \text { activation }\end{array}$ & {$[74]$} \\
\hline Tenuigenin & Polygala tenuifolia & $\begin{array}{l}\text { Human OA chondrocytes } \\
\text { induced by IL- } 1 \beta\end{array}$ & $\begin{array}{l}\text { Inhibit IL- } 1 \beta \text {-induced NO and PGE2 production, } \\
\text { suppress MMP-1, MMP-3, and MMP-13 } \\
\text { expression, and inhibit IL- } 1 \beta \text {-induced NF- } \kappa \beta \\
\text { activation, PI } 3 \mathrm{~K} \text {, and AKT phosphorylation }\end{array}$ & {$[75]$} \\
\hline $\begin{array}{l}\text { Achyranthes } \\
\text { bidentate saponins }\end{array}$ & Achyranthes bidentate & Chondrocytes of SD rats & $\begin{array}{l}\text { Suppress the activation of caspase- } 3 \text {, p } 53 \text { protein } \\
\text { phosphorylation and promote the expression of } \\
\qquad \text { Bcl-xL and Bad }\end{array}$ & [93] \\
\hline
\end{tabular}

ACLT: anterior cruciate ligament. 


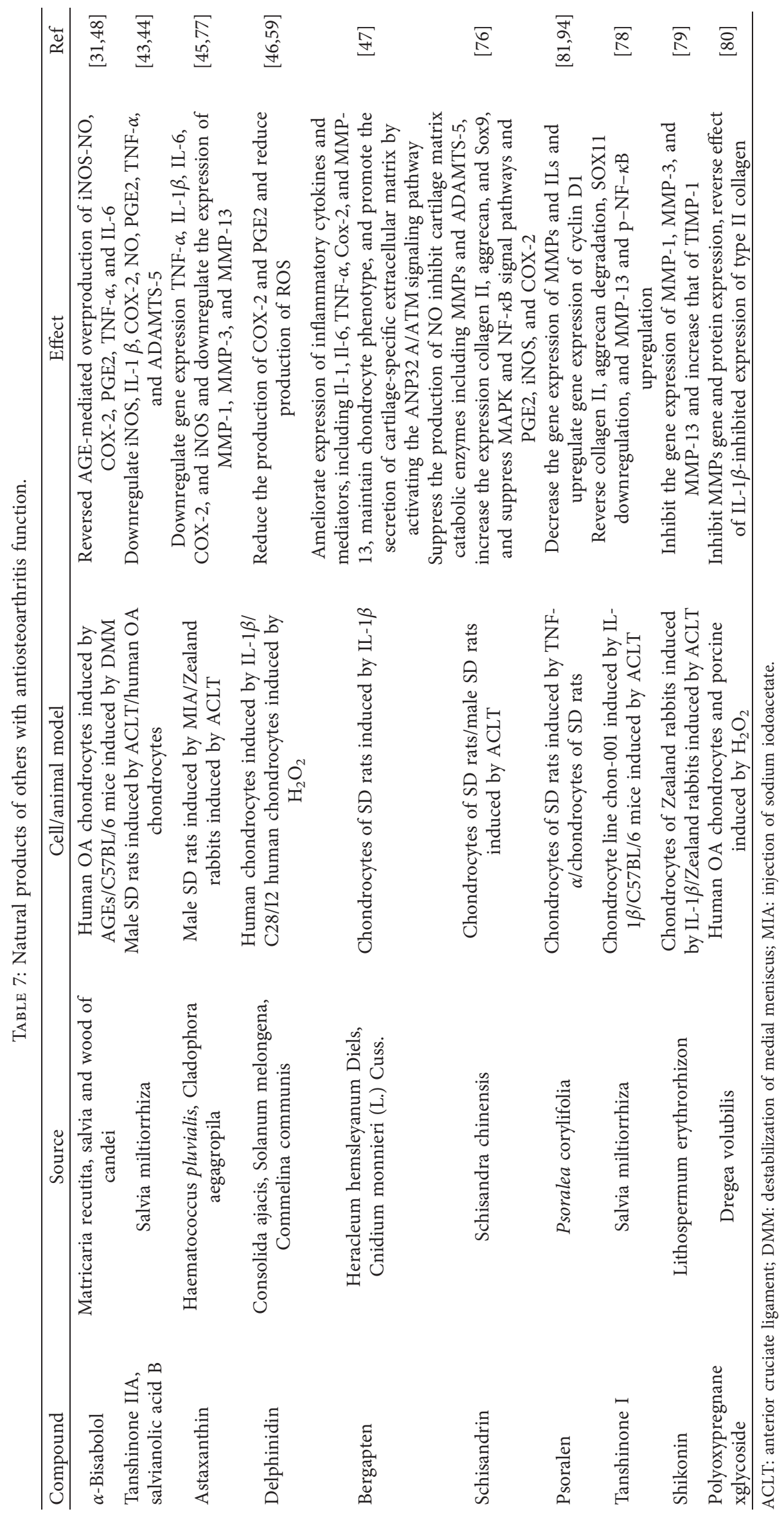




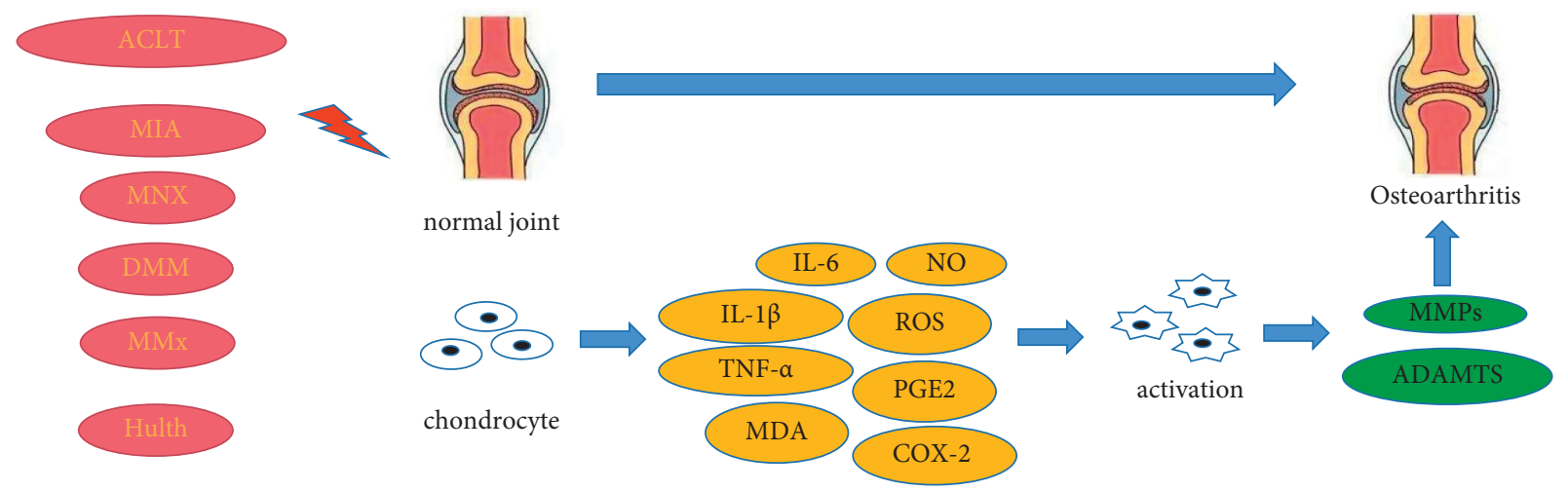

(a)
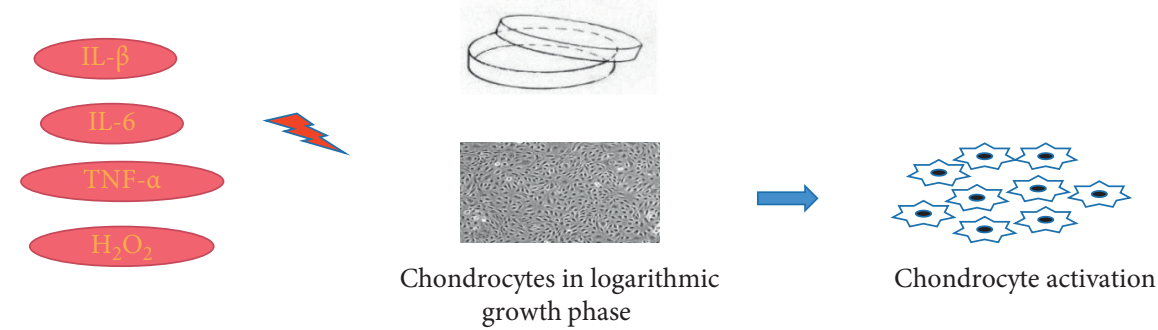

(b)

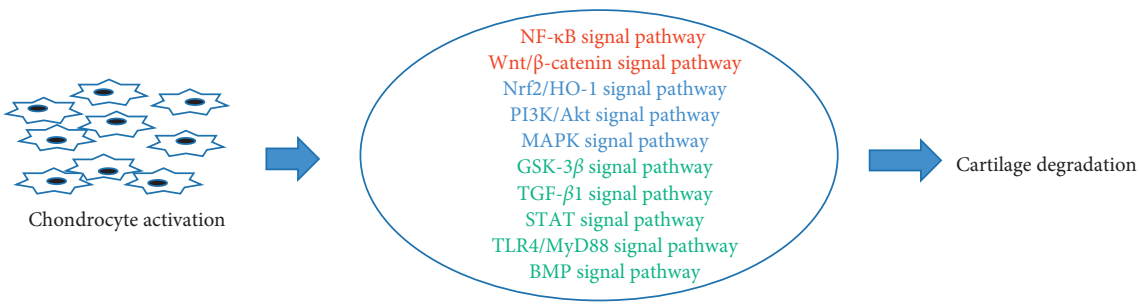

(c)

FIGURE 6: Animal models, cell models, and signaling pathways involved in the study of natural products with antiosteoarthritis effect. (a) Animal models used in the study of osteoarthritis. (b) Cell models used in the study of osteoarthritis. (c) Signaling pathways involved in the study of the mechanisms of natural products with antiosteoarthritis. The antiosteoarthritis mechanism of most natural products is related to the 2 signaling pathways marked in red. Some are related to the 3 signaling pathways marked in blue. A few are related to the 5 signaling pathways marked in green. ACLT: anterior cruciate ligament; MIA; injection of sodium iodoacetate; MNX; medial meniscectomy; DMM; destabilization of medial meniscus; MMxs; resection of medial menisci.

inflammatory drugs have potential adverse reactions in gastrointestinal tract, liver, heart, and kidney. These adverse reactions increase with the increase of dose and treatment duration [98]. In this double-blind randomized controlled trial, subjects with knee osteoarthritis received intra-articular triamcinolone acetonide or normal saline placebo every three months for two years. These results suggest that intraarticular triamcinolone acetonide cannot delay cartilage destruction, but may accelerate cartilage destruction, and the anti-inflammatory effect of steroids cannot play a role as a disease regulator [99]. Some natural products may also cause some side effects, such as hepatotoxicity, gastrointestinal discomfort, dizziness, fatigue, skin reaction, elevated serum aminotransferase level, male reproductive toxicity, and menstrual changes. Aconitine can induce a variety of arrhythmias and lead to death. Improper use of Tripterygium wilfordii may cause strong irritation of gastrointestinal tract, congestion, edema, and necrosis of gastrointestinal mucosa. It can also cause bleeding and necrosis of liver, kidney, heart, and other organs, which can directly damage the myocardium [100]. These studies show that when studying drugs for the treatment of osteoarthritis, both western medicine and natural products need to determine the dosage and toxic and side effects. Natural products need a long time in the process of treating diseases, so there are high requirements for their safety. As a way to explore new drugs, natural products should not only pay attention to the curative effect, but also pay attention to its toxicity.

Natural products are a valuable treasure house for drug selection, and their anti-OA effect is verified by experiments. This paper summarizes the anti-OA effect of natural products in the recent ten years, so as to prepare for the later research and development of lead compounds of anti-OA drugs. 


\section{Limitation}

Most natural products in this review have not undergone clinical trials, and their safety cannot be guaranteed. More clinical data are needed to prove their safety. There is still a long way to go to be on the market. The description of natural products does not start from the direct cause of OA. At present, the research depth and breadth of natural products are still very limited, and the key research needs to be further explored.

\section{Data Availability}

The data used to support the results of this study are included within the article. The data used to support the findings of this study are also available from the corresponding author upon request.

\section{Conflicts of Interest}

The authors declare that there are no conflicts of interest regarding the publication of this paper.

\section{Authors' Contributions}

Mingzhu Gao and Leilei Bao contributed to the conception and design of this review. Mingzhu Gao and Chun Chen performed searches, analyses, and interpretations. Jun Bian and Qiaoyan Zhang created the tables and figures. Luping Qin substantially revised the manuscript. All authors approved this version to be submitted.

\section{Acknowledgments}

The authors would like to thank Editage (https://www. editage.cn) for English language editing. This study was supported by the Shanghai Natural Fund (19ZR1456500) and Innovation and Generation of Military Medical Support Capability (20WQ011).

\section{References}

[1] A. C. Thomas, T. Hubbard-Turner, E. A. Wikstrom, and R. M. Palmieri-Smith, "Epidemiology of posttraumatic osteoarthritis," Journal of Athletic Training, vol. 52, no. 6, pp. 491-496, 2017.

[2] J. Shen, Y. Abu-Amer, R. J. O'Keefe, and A. McAlinden, "Inflammation and epigenetic regulation in osteoarthritis," Connective Tissue Research, vol. 58, no. 1, pp. 49-63, 2017.

[3] L. Li, H. Liu, W. Shi et al., "Insights into the action mechanisms of traditional Chinese medicine in osteoarthritis," Evidence-Based Complementary and Alternative Medicine, vol. 2017, Article ID 5190986, 13 pages, 2017.

[4] Y. Henrotin and A. Mobasheri, "Natural products for promoting joint health and managing osteoarthritis," Current Rheumatology Reports, vol. 20, no. 11, p. 72, 2018.

[5] D. Tholl, "Biosynthesis and biological functions of terpenoids in plants," Advances in Biochemical Engineering, vol. 148, pp. 63-106, 2015.

[6] S. Hortelano, L. Gonzalez-Cofrade, I. Cuadrado, and B. de Las Heras, "Current status of terpenoids as inflammasome inhibitors," Biochemical Pharmacology, vol. 172, Article ID 113739, 2020.

[7] M. Huang, J. J. Lu, M. Q. Huang, J. L. Bao, X. P. Chen, and Y. T. Wang, "Terpenoids: natural products for cancer therapy," Expert Opinion on Investigational Drugs, vol. 21, no. 12, pp. 1801-1818, 2012.

[8] Y. Chen, F. Yao, K. Ming, D. Wang, Y. Hu, and J. Liu, "Polysaccharides from traditional Chinese medicines: extraction, purification, modification, and biological activity," Molecules, vol. 2112 pages, 2016.

[9] Q. Chen, X. Shao, P. Ling, F. Liu, G. Han, and F. Wang, "Recent advances in polysaccharides for osteoarthritis therapy," European Journal of Medicinal Chemistry, vol. 139, pp. 926-935, 2017.

[10] G. Cirillo, M. Curcio, O. Vittorio et al., "Polyphenol conjugates and human health: a perspective review," Critical Reviews in Food Science and Nutrition, vol. 56, no. 2, pp. 326-337, 2016.

[11] Q. Y. Eng, P. V. Thanikachalam, and S. Ramamurthy, "Molecular understanding of Epigallocatechin gallate (EGCG) in cardiovascular and metabolic diseases," Journal of Ethnopharmacology, vol. 210, pp. 296-310, 2018.

[12] A. P. Singh, R. Singh, S. S. Verma et al., "Health benefits of resveratrol: evidence from clinical studies," Medicinal Research Reviews, vol. 39, no. 5, pp. 1851-1891, 2019.

[13] J. Wen, H. Lin, M. Zhao et al., "Piceatannol attenuates D-GalN/LPS-induced hepatoxicity in mice: involvement of ER stress, inflammation and oxidative stress," International Immunopharmacology, vol. 64, pp. 131-139, 2016.

[14] Z. Ma, X. Zhang, L. Xu et al., "Pterostilbene: mechanisms of its action as oncostatic agent in cell models and in vivo studies," Pharmacological Research, vol. 145, Article ID 104265, 2019.

[15] K. Huang, Y. Chen, R. Zhang et al., "Honokiol induces apoptosis and autophagy via the ROS/ERK1/2 signaling pathway in human osteosarcoma cells in vitro and in vivo," Cell Death and Disease, vol. 9, no. 2, p. 157, 2018.

[16] Y. S. Yi, "Regulatory roles of flavonoids on inflammasome activation during inflammatory responses," Molecular Nutrition and Food Research, vol. 62, no. 13, Article ID e1800147, 2018.

[17] N. Ren, E. Kim, B. Li et al., "Flavonoids alleviating insulin resistance through inhibition of inflammatory signaling," Journal of Agricultural and Food Chemistry, vol. 67, no. 19, pp. 5361-5373, 2019.

[18] C. Liu, S. Yang, K. Wang et al., "Alkaloids from traditional Chinese medicine against hepatocellular carcinoma," Biomedicine and Pharmacotherapy, vol. 120, Article ID 109543, 2019.

[19] S. Yan, P. C. Wei, Q. Chen et al., "Functional and structural characterization of a beta-glucosidase involved in saponin metabolism from intestinal bacteria," Biochemical and Biophysical Research Communications, vol. 496, no. 4, pp. 1349-1356, 2018.

[20] A. Fernandez-Tejada, W. E. Walkowicz, D. S. Tan, and D. Y. Gin, "Semisynthesis of analogues of the saponin immunoadjuvant QS-21," Methods in Molecular Biology, vol. 1494, pp. 45-71, 2017.

[21] W. Ru, D. Wang, Y. Xu et al., "Chemical constituents and bioactivities of Panax ginseng (C. A. Mey.)," Drug Discoveries and Therapeutics, vol. 9, no. 1, pp. 23-32, 2015.

[22] Y. N. Song, S. Dong, B. Wei, P. Liu, Y. Y. Zhang, and S. B. Su, "Metabolomic mechanisms of gypenoside against liver fibrosis in rats: an integrative analysis of proteomics and 
metabolomics data," PLoS One, vol. 12, no. 3, Article ID e0173598, 2017.

[23] Y. J. Chen, X. B. Huang, Z. X. Li, L. L. Yin, W. Q. Chen, and L. Li, "Tenuigenin protects cultured hippocampal neurons against methylglyoxal-induced neurotoxicity," European Journal of Pharmacology, vol. 645, no. 1-3, pp. 1-8, 2010.

[24] J. Fu, H. Wu, H. Wu, R. Deng, and F. Li, "Chemical and metabolic analysis of Achyranthes bidentate saponins with intestinal microflora-mediated biotransformation by ultraperformance liquid chromatography-quadrupole time-offlight mass spectrometry coupled with metabolism platform," Journal of Pharmaceutical and Biomedical Analysis, vol. 170, pp. 305-320, 2019.

[25] L. Peeters, C. Beirnaert, A. Van der Auwera et al., "Revelation of the metabolic pathway of hederacoside $C$ using an innovative data analysis strategy for dynamic multiclass biotransformation experiments," Journal of Chromatography A, vol. 1595, pp. 240-247, 2019.

[26] C. Y. Su, Q. L. Ming, K. Rahman, T. Han, and L. P. Qin, "Salvia miltiorrhiza: traditional medicinal uses, chemistry, and pharmacology," Chinese Journal of Natural Medicines, vol. 13, no. 3, pp. 163-182, 2015.

[27] B. Yu, D. Sheng, and Q. Tan, "Determination of schisandrin $A$ and schisandrin $B$ in traditional Chinese medicine preparation huganpian tablet by RP-HPLC," Chemical and Pharmaceutical Bulletin, vol. 67, no. 7, pp. 713-716, 2019.

[28] X. Wang, P. Peng, Z. Pan, Z. Fang, W. Lu, and X. Liu, "Psoralen inhibits malignant proliferation and induces apoptosis through triggering endoplasmic reticulum stress in human SMMC7721 hepatoma cells," Biological Research, vol. 52, no. 1, p. 34, 2019.

[29] S. P. Pattanayak, P. Bose, P. Sunita, M. U. M. Siddique, and A. Lapenna, "Bergapten inhibits liver carcinogenesis by modulating LXR/PI3K/Akt and IDOL/LDLR pathways," Biomedicine and Pharmacotherapy, vol. 108, pp. 297-308, 2018.

[30] K. Zheng, G. Zhang, N. Jiang et al., "Analysis of the transcriptome of Marsdenia tenacissima discovers putative polyoxypregnane glycoside biosynthetic genes and genetic markers," Genomics, vol. 104, no. 3, pp. 186-193, 2014.

[31] V. M. Munoz-Perez, M. I. Ortiz, H. A. Ponce-Monter, V. Monter-Perez, and G. Barragan-Ramirez, "Anti-inflammatory and utero-relaxant effect of alpha-bisabolol on the pregnant human uterus," Korean Journal of Physiology and Pharmacology, vol. 22, no. 4, pp. 391-398, 2018.

[32] I. C. Young, S. T. Chuang, C. H. Hsu et al., "Protective effects of aucubin on osteoarthritic chondrocyte model induced by hydrogen peroxide and mechanical stimulus," BMC Complementary and Alternative Medicine, vol. 17, no. 1, p. 91, 2017.

[33] S. Kang, J. Zhang, and Y. Yuan, "Abietic acid attenuates ILlbeta-induced inflammation in human osteoarthritis chondrocytes," International Immunopharmacology, vol. 64, pp. 110-115, 2018.

[34] C. Zhuang, N. W. Xu, G. M. Gao et al., "Polysaccharide from Angelica sinensis protects chondrocytes from $\mathrm{H}_{2} \mathrm{O}_{2}$-induced apoptosis through its antioxidant effects in vitro," International Journal of Biological Macromolecules, vol. 87, pp. 322-328, 2016.

[35] L. F. Heinecke, M. W. Grzanna, A. Y. Au, C. A. Mochal, A. Rashmir-Raven, and C. G. Frondoza, "Inhibition of cyclooxygenase-2 expression and prostaglandin E2 production in chondrocytes by avocado soybean unsaponifiables and epigallocatechin gallate," Osteoarthritis and Cartilage, vol. 18, no. 2, pp. 220-227, 2010.

[36] Y. J. Chen, K. S. Tsai, D. C. Chan et al., "Honokiol, a low molecular weight natural product, prevents inflammatory response and cartilage matrix degradation in human osteoarthritis chondrocytes," Journal of Orthopaedic Research, vol. 32, no. 4, pp. 573-580, 2014.

[37] J. S. Oh, I. A. Cho, K. R. Kang et al., "Biochanin-A antagonizes the interleukin-1beta-induced catabolic inflammation through the modulation of NFkappaB cellular signaling in primary rat chondrocytes," Biochemical and Biophysical Research Communications, vol. 477, no. 4, pp. 723-730, 2016.

[38] X. Yang, Q. Zhang, Z. Gao, C. Yu, and L. Zhang, "Baicalin alleviates IL-1beta-induced inflammatory injury via downregulating miR-126 in chondrocytes," Biomedicine and Pharmacotherapy, vol. 99, pp. 184-190, 2018.

[39] Y. Wu, Z. Lin, Z. Yan, Z. Wang, X. Fu, and K. Yu, "Sinomenine contributes to the inhibition of the inflammatory response and the improvement of osteoarthritis in mousecartilage cells by acting on the Nrf2/HO-1 and NF-kappaB signaling pathways," International Immunopharmacology, vol. 75, Article ID 105715, 2019.

[40] Y. Wei, J. Jia, X. Jin, W. Tong, and H. Tian, "Resveratrol ameliorates inflammatory damage and protects against osteoarthritis in a rat model of osteoarthritis," Molecular Medicine Reports, vol. 17, no. 1, pp. 1493-1498, 2018.

[41] A Courties, A Do, S. Leite et al., "The role of the nonneuronal cholinergic system in inflammation and degradation processes in osteoarthritis," Arthritis and Rheumatism, vol. 72, no. 12, pp. 2072-2082, 2020.

[42] H. Li, Y. Peng, X. Wang et al., "Astragaloside inhibits IL1beta-induced inflammatory response in human osteoarthritis chondrocytes and ameliorates the progression of osteoarthritis in mice," Immunopharmacology and Immunotoxicology, vol. 41, no. 4, pp. 497-503, 2019.

[43] P. T. Jia, X. L. Zhang, H. N. Zuo, X. Lu, and L. Li, “Articular cartilage degradation is prevented by tanshinone IIA through inhibiting apoptosis and the expression of inflammatory cytokines," Molecular Medicine Reports, vol. 16, no. 5, pp. 6285-6289, 2017.

[44] Y. Lou, C. Wang, W. Zheng et al., "Salvianolic acid B inhibits IL-1beta-induced inflammatory cytokine production in human osteoarthritis chondrocytes and has a protective effect in a mouse osteoarthritis model," International Immunopharmacology, vol. 46, pp. 31-37, 2017.

[45] M. H. Park, J. C. Jung, S. Hill et al., "FlexPro $M D(R)$, a combination of krill oil, astaxanthin and hyaluronic acid, reduces pain behavior and inhibits inflammatory response in monosodium iodoacetate-induced osteoarthritis in rats," Nutrients, vol. 12, 4 pages, 2020.

[46] A. Haseeb, D. Chen, and T. M. Haqqi, "Delphinidin inhibits IL-1beta-induced activation of NF-kappaB by modulating the phosphorylation of IRAK-1(Ser376) in human articular chondrocytes," Rheumatology, vol. 52, no. 6, pp. 998-1008, 2013.

[47] Y. He, Z. Zisan, Z. Lu, L. Zheng, and J. Zhao, "Bergapten alleviates osteoarthritis by regulating the ANP32A/ATM signaling pathway," FEBS Open Bio, vol. 9, no. 6, pp. 1144-1152, 2019.

[48] C. Xu, S. Sheng, H. Dou et al., "Alpha-Bisabolol suppresses the inflammatory response and ECM catabolism in advanced glycation end products-treated chondrocytes and attenuates murine osteoarthritis," International Immunopharmacology, vol. 84, Article ID 106530, 2020. 
[49] B. Li, T. Jiang, H. Liu et al., "Andrographolide protects chondrocytes from oxidative stress injury by activation of the Keap1-Nrf2-Are signaling pathway," Journal of Cellular Physiology, vol. 234, no. 1, pp. 561-571, 2018.

[50] K. K. Ajeeshkumar, K. V. Vishnu, R. Navaneethan et al., "Proteoglycans isolated from the bramble shark cartilage show potential anti-osteoarthritic properties," Inflammopharmacology, vol. 27, no. 1, pp. 175-187, 2019.

[51] L. Wen, T. B. Qu, K. Zhai, J. Ding, Y. Hai, and J. L. Zhou, "Gallic acid can play a chondroprotective role against AGEinduced osteoarthritis progression," Journal of Orthopaedic Science, vol. 20, no. 4, pp. 734-741, 2015.

[52] E. X. Xue, J. P. Lin, Y. Zhang et al., "Pterostilbene inhibits inflammation and ROS production in chondrocytes by activating Nrf2 pathway," Oncotarget, vol. 8, no. 26, pp. 41988-42000, 2017.

[53] Y. Pan, D. Chen, Q. Lu, L. Liu, X. Li, and Z. Li, "Baicalin prevents the apoptosis of endplate chondrocytes by inhibiting the oxidative stress induced by $\mathrm{H} 2 \mathrm{O} 2$," Molecular Medicine Reports, vol. 16, no. 3, pp. 2985-2991, 2017.

[54] F. Estakhri, M. R. Panjehshahin, N. Tanideh et al., "The effect of kaempferol and apigenin on allogenic synovial membrane-derived stem cells therapy in knee osteoarthritic male rats," The Knee, vol. 27, no. 3, pp. 817-832, 2020.

[55] F. Zhou, J. Mei, K. Yuan, X. Han, H. Qiao, and T. Tang, "Isorhamnetin attenuates osteoarthritis by inhibiting osteoclastogenesis and protecting chondrocytes through modulating reactive oxygen species homeostasis," Journal of Cellular and Molecular Medicine, vol. 23, no. 6, pp. 4395-4407, 2019.

[56] G. Gao, H. Ding, C. Zhuang, and W. Fan, "Effects of hesperidin on $\mathrm{H}(2) \mathrm{O}(2)$-treated chondrocytes and cartilage in a rat osteoarthritis model," Medical Science Monitor, vol. 24, pp. 9177-9186, 2018.

[57] T. Yu, J. Qu, Y. Wang, and H. Jin, "Ligustrazine protects chondrocyte against IL-1beta induced injury by regulation of SOX9/NF-kappaB signaling pathway," Journal of Cellular Biochemistry, vol. 119, no. 9, pp. 7419-7430, 2018.

[58] H. C. Xu, B. Wu, Y. M. Ma, H. Xu, Z. H. Shen, and S. Chen, "Hederacoside-C protects against AGEs-induced ECM degradation in mice chondrocytes," International Immunopharmacology, vol. 84, Article ID 106579, 2020.

[59] D. Y. Lee, Y. J. Park, M. G. Song, D. R. Kim, S. Zada, and D. H. Kim, "Cytoprotective effects of delphinidin for human chondrocytes against oxidative stress through activation of autophagy," Antioxidants, vol. 91 page, 2020.

[60] Q. Tang, Z. Feng, M. Tong et al., "Piceatannol inhibits the ILlbeta-induced inflammatory response in human osteoarthritic chondrocytes and ameliorates osteoarthritis in mice by activating Nrf2," Food and Function, vol. 8, no. 11, pp. 3926-3937, 2020.

[61] P. Teng, Y. Liu, Y. Dai, H. Zhang, W. T. Liu, and J. Hu, "Nicotine attenuates osteoarthritis pain and matrix metalloproteinase- 9 expression via the alpha7 nicotinic acetylcholine receptor," The Journal of Immunology, vol. 203, no. 2, pp. 485-492, 2019.

[62] H. Zhao, T. Zhang, C. Xia et al., "Berberine ameliorates cartilage degeneration in interleukin-1beta-stimulated rat chondrocytes and in a rat model of osteoarthritis via Akt signalling," Journal of Cellular and Molecular Medicine, vol. 18, no. 2, pp. 283-292, 2014.

[63] L. Qiu, Y. Luo, and X. Chen, "Quercetin attenuates mitochondrial dysfunction and biogenesis via upregulated
AMPK/SIRT1 signaling pathway in OA rats," Biomedicine and Pharmacotherapy, vol. 103, pp. 1585-1591, 2018.

[64] B. Wei, Y. Zhang, L. Tang, Y. Ji, C. Yan, and X. Zhang, "Protective effects of quercetin against inflammation and oxidative stress in a rabbit model of knee osteoarthritis," Drug Development Research, vol. 80, no. 3, pp. 360-367, 2019.

[65] D. A. Permatasari, D. Karliana, I. Iskandarsyah, A. Arsianti, and A. Bahtiar, "Quercetin prevent proteoglycan destruction by inhibits matrix metalloproteinase-9, matrix metalloproteinase-13, a disintegrin and metalloproteinase with thrombospondin motifs-5 expressions on osteoarthritis model rats," Journal of Advanced Pharmaceutical Technology and Research, vol. 10, no. 1, pp. 2-8, 2019.

[66] C. Chen, C. Zhang, L. Cai et al., "Baicalin suppresses IL1beta-induced expression of inflammatory cytokines via blocking NF-kappaB in human osteoarthritis chondrocytes and shows protective effect in mice osteoarthritis models," International Immunopharmacology, vol. 52, pp. 218-226, 2017.

[67] F. Wang, L. Wu, L. Li, and S. Chen, "Monotropein exerts protective effects against IL-1beta-induced apoptosis and catabolic responses on osteoarthritis chondrocytes," International Immunopharmacology, vol. 23, no. 2, pp. 575-580, 2014.

[68] D. Zhang, B. Huang, C. Xiong, and Z. Yue, "Pinocembrin inhibits matrix metalloproteinase expression in chondrocytes," IUBMB Life, vol. 67, no. 1, pp. 36-41, 2015.

[69] D. Q. Wu, H. M. Zhong, Q. H. Ding, and L. Ba, "Protective effects of biochanin A on articular cartilage: in vitro and in vivo studies," BMC Complementary and Alternative Medicine, vol. 14, p. 444, 2014.

[70] G. J. Lee, I. A. Cho, K. R. Kang et al., "Biological effects of the herbal plant-derived phytoestrogen bavachin in primary rat chondrocytes," Biological and Pharmaceutical Bulletin, vol. 38, no. 8, pp. 1199-1207, 2015.

[71] L. Zeng, W. Wang, X. F. Rong et al., "Chondroprotective effects and multi-target mechanisms of Icariin in IL-1 betainduced human SW 1353 chondrosarcoma cells and a rat osteoarthritis model," International Immunopharmacology, vol. 18, no. 1, pp. 175-181, 2014.

[72] L. Zhao, J. Ye, G. T. Wu, X. J. Peng, P. F. Xia, and Y. Ren, "Gentiopicroside prevents interleukin-1 beta induced inflammation response in rat articular chondrocyte," Journal of Ethnopharmacology, vol. 172, pp. 100-107, 2015.

[73] W. Cheng, J. Jing, Z. Wang, D. Wu, and Y. Huang, "Chondroprotective effects of ginsenoside Rg1 in human osteoarthritis chondrocytes and a rat model of anterior cruciate ligament transection," Nutrients, vol. 93 pages, 2017.

[74] Z. H. Wan and Q. Zhao, "Gypenoside inhibits interleukinlbeta-induced inflammatory response in human osteoarthritis chondrocytes," Journal of Biochemical and Molecular Toxicology, vol. 31, no. 9, 2017.

[75] C. Wang, L. Zeng, T. Zhang, J. Liu, and W. Wang, “Tenuigenin prevents IL-1beta-induced inflammation in human osteoarthritis chondrocytes by suppressing PI3K/AKT/NFkappaB signaling pathway," Inflammation, vol. 39, no. 2, pp. 807-812, 2016.

[76] C. Tu, X. Huang, Y. Xiao et al., "Schisandrin A inhibits the IL-1beta-induced inflammation and cartilage degradation via suppression of MAPK and NF-kappaB signal pathways in rat chondrocytes," Frontiers in Pharmacology, vol. 10, p. 41, 2019. 
[77] L. J. Huang and W. P. Chen, "Astaxanthin ameliorates cartilage damage in experimental osteoarthritis," Modern Rheumatology, vol. 25, no. 5, pp. 768-771, 2015.

[78] X. Wang, J. Fan, X. Ding, Y. Sun, Z. Cui, and W. Liu, "Tanshinone I inhibits IL-1beta-induced apoptosis, inflammation and extracellular matrix degradation in chondrocytes CHON-001 cells and attenuates murine osteoarthritis," Drug Design, Development and Therapy, vol. 13, pp. 3559-3568, 2019.

[79] F. Li, Z. Yin, B. Zhou et al., "Shikonin inhibits inflammatory responses in rabbit chondrocytes and shows chondroprotection in osteoarthritic rabbit knee," International Immunopharmacology, vol. 29, no. 2, pp. 656-662, 2015.

[80] A. Itthiarbha, T. Phitak, S. Sanyacharernkul, P. Pothacharoen, W. Pompimon, and P. Kongtawelert, "Polyoxypregnane glycoside from Dregea volubilis extract inhibits IL-1beta-induced expression of matrix metalloproteinase via activation of NF-kappaB in human chondrocytes," In Vitro Cellular \& Developmental Biology Animal, vol. 48, no. 1, pp. 43-53, 2012.

[81] C. Wang, M. K. Al-Ani, Y. Sha et al., "Psoralen protects chondrocytes, exhibits anti-inflammatory effects on synoviocytes, and attenuates monosodium iodoacetate-induced osteoarthritis," International Journal of Biological Sciences, vol. 15, no. 1, pp. 229-238, 2019.

[82] Z. Li, Y. Wang, S. Xiang et al., "Chondrocytes-derived exosomal miR-8485 regulated the Wnt/beta-catenin pathways to promote chondrogenic differentiation of BMSCs," Biochemical and Biophysical Research Communications, vol. 523, no. 2, pp. 506-513, 2019.

[83] B. W. Wang, Y. Jiang, Z. L. Yao, P. S. Chen, B. Yu, and S. N. Wang, "Aucubin protects chondrocytes against ILlbeta-induced apoptosis in vitro and inhibits osteoarthritis in mice model," Drug Design, Development and Therapy, vol. 13, pp. 3529-3538, 2019.

[84] K. Feng, H. Chen, and C. Xu, "Chondro-protective effects of celastrol on osteoarthritis through autophagy activation and NF-kappaB signaling pathway inhibition," Inflammation Research, vol. 69, no. 4, pp. 385-400, 2020.

[85] G. Zhang, H. Zhang, W. You, X. Tang, X. Li, and Z. Gong, "Therapeutic effect of Resveratrol in the treatment of osteoarthritis via the MALAT1/miR-9/NF-kappaB signaling pathway," Experimental and Therapeutic Medicine, vol. 19, no. 3, pp. 2343-2352, 2020.

[86] D. Song, Z. Cao, S. Huang et al., "Achyranthes bidentata polysaccharide suppresses osteoclastogenesis and bone resorption via inhibiting RANKL signaling," Journal of Cellular Biochemistry, vol. 119, no. 6, pp. 4826-4835, 2018.

[87] X. Weng, P. Lin, F. Liu et al., "Achyranthes bidentata polysaccharides activate the Wnt/beta-catenin signaling pathway to promote chondrocyte proliferation," International Journal of Molecular Medicine, vol. 34, no. 4, pp. 1045-1050, 2014.

[88] C. Fu, C. Zheng, J. Lin et al., "Cibotium barometz polysaccharides stimulate chondrocyte proliferation in vitro by promoting G1/S cell cycle transition," Molecular Medicine Reports, vol. 15, no. 5, pp. 3027-3034, 2017.

[89] J. Y. Na, K. Song, S. Kim, and J. Kwon, "Rutin protects rat articular chondrocytes against oxidative stress induced by hydrogen peroxide through SIRT1 activation," Biochemical and Biophysical Research Communications, vol. 473, no. 4, pp. 1301-1308, 2016.

[90] J. Liu, Q. Meng, H. Jing, and S. Zhou, "Astragaloside IV protects against apoptosis in human degenerative chondrocytes through autophagy activation," Molecular Medicine Reports, vol. 16, no. 3, pp. 3269-3275, 2017.

[91] Y. Zhou, H. Tao, Y. Li et al., "Berberine promotes proliferation of sodium nitroprusside-stimulated rat chondrocytes and osteoarthritic rat cartilage via Wnt/beta-catenin pathway," European Journal of Pharmacology, vol. 789, pp. 109-118, 2016.

[92] X. Zheng, C. Xia, Z. Chen et al., "Requirement of the phosphatidylinositol 3-kinase/Akt signaling pathway for the effect of nicotine on interleukin-1beta-induced chondrocyte apoptosis in a rat model of osteoarthritis," Biochemical and Biophysical Research Communications, vol. 423, no. 3, pp. 606-612, 2012.

[93] X. X. Xu, X. H. Zhang, Y. Diao, and Y. X. Huang, "Achyranthes bidentate saponins protect rat articular chondrocytes against interleukin-1beta-induced inflammation and apoptosis in vitro," The Kaohsiung Journal of Medical Sciences, vol. 33, no. 2, pp. 62-68, 2017.

[94] W. Zheng, P. Lin, Y. Ma et al., "Psoralen promotes the expression of cyclin D1 in chondrocytes via the Wnt/betacatenin signaling pathway," International Journal of Molecular Medicine, vol. 40, no. 5, pp. 1377-1384, 2017.

[95] G. P. Dobson, H. L. Letson, A. Grant et al., "Defining the osteoarthritis patient: back to the future," Osteoarthritis and Cartilage, vol. 26, no. 8, pp. 1003-1007, 2018.

[96] A. E. Nelson, "Osteoarthritis year in review 2017: clinical," Osteoarthritis and Cartilage, vol. 26, no. 3, pp. 319-325, 2018.

[97] H. S. Kan, P. K. Chan, K. Y. Chiu et al., "Non-surgical treatment of knee osteoarthritis," Hong Kong Medical Journal, vol. 25, no. 2, pp. 127-133, 2019.

[98] M. Jóźwiak-Bebenista and J. Z. Nowak, "Paracetamol: mechanism of action, applications and safety concern," Acta Poloniae Pharmaceutica, vol. 71, no. 1, pp. 11-23, 2014.

[99] D. Shep, C. Khanwelkar, P. Gade, S. Karad, and D. Ortho, "Efficacy and safety of combination of curcuminoid complex and diclofenac versus diclofenac in knee osteoarthritis: A randomized trial," Medicine (Baltimore), vol. 99, no. 16, Article ID e19723, 2020.

[100] B. N. Lindler, K. E. Long, N. A. Taylor, and W. Lei, "Use of herbal medications for treatment of osteoarthritis and rheumatoid arthritis," Medicines (Basel), vol. 7, no. 11, p. 67, 2020 . 